\title{
Identification of a set of KSRP target transcripts upregulated by PI3K-AKT signaling
}

\author{
Tina Ruggiero $^{\dagger 1}$, Michele Trabucchi ${ }^{\dagger 1}$, Marco Ponassi ${ }^{1}$, Giorgio Corte ${ }^{1,2}$, \\ Ching-Yi Chen ${ }^{3}$, Latifa al-Haj ${ }^{4}$, Khalid SA Khabar ${ }^{4}$, Paola Briata ${ }^{\dagger 1}$ and \\ Roberto Gherzi*†1
}

\begin{abstract}
Address: ${ }^{1}$ Istituto Nazionale per la Ricerca sul Cancro (IST), 16132 Genova, Italy, ${ }^{2}$ DOBIG, University of Genova, 16132 Genova, Italy, ${ }^{3}$ Department of Biochemistry and Molecular Genetics, University of Alabama at Birmingham, Birmingham, AL 35294, USA and 4 Program in Biomolecular Research, King Faisal Specialist Hospital and Research Center, Riyadh 11211, Saudi Arabia

Email: Tina Ruggiero - tina.ruggiero@istge.it; Michele Trabucchi - mtrabucc@ucsd.edu; Marco Ponassi - marco.ponassi@istge.it; Giorgio Corte - giorgio.corte@istge.it; Ching-Yi Chen - cchen@uab.edu; Latifa al-Haj - alhaj@kfshrc.edu.sa;

Khalid SA Khabar - khabar@kfshrc.edu.sa; Paola Briata - pbriata@yahoo.com; Roberto Gherzi* - rgherzi@ucsd.edu

* Corresponding author †Equal contributors
\end{abstract}

Published: 16 April 2007

BMC Molecular Biology 2007, 8:28 doi:10.1186/147/-2199-8-28

This article is available from: http://www.biomedcentral.com/I47I-2199/8/28

(c) 2007 Ruggiero et al; licensee BioMed Central Ltd.

This is an Open Access article distributed under the terms of the Creative Commons Attribution License (http://creativecommons.org/licenses/by/2.0), which permits unrestricted use, distribution, and reproduction in any medium, provided the original work is properly cited.
Received: 19 December 2006

Accepted: 16 April 2007

\begin{abstract}
Background: KSRP is a AU-rich element (ARE) binding protein that causes decay of select sets of transcripts in different cell types. We have recently described that phosphatidylinositol 3-kinase/ AKT (PI3K-AKT) activation induces stabilization and accumulation of the labile $\beta$-catenin mRNA through an impairment of KSRP function.

Results: Aim of this study was to identify additional KSRP targets whose stability and steady-state levels are enhanced by PI3K-AKT activation. First, through microarray analyses of the AU-rich transcriptome in pituitary $\alpha \mathrm{T} 3-\mathrm{I}$ cells, we identified 34 ARE-containing transcripts upregulated in cells expressing a constitutively active form of AKTI. In parallel, by an affinity chromatographybased technique followed by microarray analyses, 12 mRNAs target of KSRP, additional to $\beta$ catenin, were identified. Among them, seven mRNAs were upregulated in cells expressing activated AKTI. Both steady-state levels and stability of these new KSRP targets were consistently increased by either KSRP knock-down or PI3K-AKT activation.

Conclusion: Our study identified a set of transcripts that are targets of KSRP and whose expression is increased by PI3K-AKT activation. These mRNAs encode RNA binding proteins, signaling molecules and a replication-independent histone. The increased expression of these gene products upon PI3K-AKT activation could play a role in the cellular events initiated by this signaling pathway.
\end{abstract}

\section{Background}

Regulated mRNA decay is a key factor in determining the expression pattern of many genes including those encoding for cytokines, proto-oncogenes, cell cycle regulators, and growth factors [1]. Adenylate-uridylate-rich elements (AREs), present in the 3'-untranslated region (3'UTR) of many inherently labile mRNAs, are the most widespread and best characterized destabilizing sequences $[1,2]$. 
Impairment of the ARE-mediated mRNA decay results in abnormal cell proliferation and angiogenesis, leading to cancer insurgence and progression [3], as well as in inflammatory diseases such as Crohn-like inflammatory bowel disease and inflammatory arthritis [4].

The interaction of regulatory proteins, ARE-binding proteins (ARE-BPs), with their target labile mRNAs determines the half-life $(\mathrm{t} 1 / 2)$ of these transcripts. Some AREBPs are decay-promoting factors (TTP, BRF1, KSRP) [1]. Others, such as HuR, are stabilizing factors, whereas AUF1 mainly promotes decay although certain isoforms might be stabilizers of ARE-containing mRNAs [1,5,6]. According to the recently proposed recruitment model, destabilizing ARE-BPs, recruit the enzymatic degradation machinery to their target mRNAs [7-9].

We and others have recently reported that KSRP promotes rapid decay of several ARE-containing mRNAs both in vitro and in vivo and that extracellular stimuli regulate its activity $[7,10-13]$. We have shown that activation of either Wnt/ $\beta$-catenin pathway in $\alpha$ T3-1 cells [10] or MAPK p38 signaling in $\mathrm{C} 2 \mathrm{C} 12$ myoblasts [11] selectively regulates the stability of specific sets of labile mRNAs targeting KSRP. More recently, we demonstrated that phosphatidylinositol 3-kinase/AKT (PI3K-AKT) signaling activation induces stabilization and enhances the steady-state levels of $\beta$-catenin mRNA in pituitary $\alpha$ T3-1 cell line through phosphorylation and functional inactivation of KSRP [12]. PI3K-AKT signaling exerts a central role in metabolism, cell survival, motility, transcription and cell-cycle progression [[12] and literature cited therein].

It has been recently suggested that control of mRNA decay is utilized by the cell to coordinate the expression of genes involved in specific processes leading to the notion of 'post-transcriptional operons' [14]. This would allow multiple genes to be co-regulated by a similar array of RNAbinding proteins in response to certain stimuli. On this basis, we hypothesized that PI3K-AKT activation could regulate the expression of transcripts additional to $\beta$-catenin by targeting KSRP. According to this hypothesis, a subset of KSRP target transcripts should be stabilized in response to PI3K-AKT signaling.

To verify this hypothesis, we systematically searched, among the AU-rich transcriptome, for KSRP target transcripts whose expression was upregulated by PI3K-AKT signaling. We identified a set of labile mRNAs, stabilized upon either KSRP knock-down or PI3K-AKT activation, encoding signaling factors, RNA binding proteins, and a replication-independent histone. These proteins could play a role in the cascade of cellular events initiated by PI3K-AKT activation.

\section{Results \\ Identification of KSRP target transcripts upregulated in cells expressing constitutively active myrAKTI}

We recently found by microarray analyses of the AU-rich transcriptome that $\beta$-catenin mRNA is stabilized and upregulated by PI3K-AKT signaling in $\alpha \mathrm{T} 3-1$ cells in a KSRP-regulated manner [12]. To systematically search for inherently labile transcripts whose expression is induced by PI3K-AKT activation, we compared RNA expression profiles of mock-transfected $\alpha \mathrm{T} 3-1$ cells (mock- $\alpha \mathrm{T} 3-1$ ) to those of $\alpha \mathrm{T} 3-1$ cells expressing a constitutively active AKT1 ( $\alpha$ T3-1-myrAKT1 [12]) using the AU-rich elementbased cDNA microarrays [15]. This array system contains approximately 2500 cDNA probes for ARE-containing mRNAs and over $1000 \mathrm{cDNA}$ probes for non-ARE mRNAs and control housekeeping genes (Additional file 1). For each cell line we obtained expression profiles from two independent RNA samples. As shown in Table 1, we identified 35 transcripts at least twofold overrepresented in $\alpha$ T3-1-myrAKT1 when compared to mock- $\alpha$ T3-1 cells. Among these, $\beta$-catenin mRNA has been previously reported and characterized (see above, [12]). All the identified transcripts display AREs in their 3'UTR and encode proteins belonging to distinct functional categories (Table 1).

In parallel, in order to identify mRNA targets of KSRP in $\alpha$ T3- 1 cells, we adopted the SNAAP technique (isolation of specific nucleic acids associated with proteins) developed by Kiledjian and coworkers [16] using GST-fused KSRP as the affinity chromatography matrix. This technique allows to isolate only those mRNAs for which the fusion protein of interest has a high affinity at the physiological salt concentrations in the context of a ribonucleoprotein complex [16]. The identification of KSRP-bound mRNAs was performed by screening the AU-rich elementbased cDNA microarrays [15]. Sequence analysis performed on 314 KSRP-interacting mRNAs identified by SNAAP (transcripts upregulated by at least 1.8-fold in KSRP-bound samples), demonstrated over-representation of ARE motifs when compared to 314 non-KSRP target transcripts (Additional file 2). Eighty genes whose mRNAs interacted with KSRP $\left(\log _{2}\right.$ ratio $>1.5$, see Additional file 3 ) were identified. Thirteen of these mRNAs (including previously characterized $\beta$-catenin mRNA [12]) displayed a more than 3 fold enrichment (our arbitrary cutoff) over the control GST matrix and were considered for further analysis (Table 2). In order to select KSRP target transcripts whose expression is induced by PI3K-AKT activation, we performed a comparative analysis of the results of the two screenings. We sorted out seven unanticipated mRNAs that were both enriched upon SNAAP isolation and over-represented in $\alpha \mathrm{T} 3-1$-myrAKT1 cells (typed in bold in Table 1). These transcripts encode three distinct RNA binding proteins, hnRNPA1, hnRNPF, and hnRNPA/ 
Table I: Transcripts whose levels are increased by at least 2 fold in $\alpha$ T3-myrAKTI when compared with mock- $\alpha$ T3. Transcripts identified as KSRP targets (see Table 3) are typed in bold.

\begin{tabular}{|c|c|c|c|c|}
\hline & Transcript name & Accession number & Protein function & Fold increase \\
\hline 1 & $\begin{array}{l}\text { CDP-diacylglycerol-inositol 3- } \\
\text { phosphatidyltransferase } \\
\text { (phosphatidylinositol synthase) }\end{array}$ & NM_006319 & Catalyzes the biosynthesis of phosphatidylinositol. & 3.74 \\
\hline 2 & $\begin{array}{l}\text { SNAP9I, synaptosomal- } \\
\text { associated protein, } 91 \mathrm{kDa} \\
\text { homolog }\end{array}$ & NM_0I484I & Component of clathrin-coated vescicles. & 3.71 \\
\hline 3 & $\begin{array}{l}\text { Solute carrier organic anion } \\
\text { transporter family, member } \mathrm{ICI}\end{array}$ & NM_017435.2 & $\begin{array}{l}\text { Mediates the } \mathrm{Na}(+) \text {-independent high affinity transport of organic anions such as the thyroid } \\
\text { hormones thyroxine (T4) and rT3. }\end{array}$ & 3.39 \\
\hline 4 & $\begin{array}{l}\text { Heterogeneous nuclear } \\
\text { ribonucleoprotein F } \\
\text { (hnRNPF) }\end{array}$ & NM_004966 & RNA binding protein, splicing. & 3.20 \\
\hline 5 & Fibroblast growth factor 5 & NM_004464 & Oncogene, can transform NIH 3 T3 cells. & 3.20 \\
\hline 6 & $\begin{array}{l}\text { Tankyrase, TRFI-interacting } \\
\text { ankyrin-related ADP-ribose } \\
\text { polymerase } 2\end{array}$ & NM_025235.2 & Involved in the regulation of telomere length. & 3.15 \\
\hline 7 & Fibroblast growth factor 19 & NM_005II7 & Has a role in brain development, overexpressed in colon adenocarcinoma cell line. & 3.12 \\
\hline 8 & $\begin{array}{l}\text { Heterogeneous nuclear } \\
\text { ribonucleoprotein A/B } \\
\text { (hnRNPA/B) }\end{array}$ & M65028 & RNA binding protein. & 3.11 \\
\hline 9 & $\begin{array}{l}\text { Microtubule-associated protein } \\
\text { RP/EB family member I }\end{array}$ & NM_0I2325 & Component of the microtubule cytoskeleton. & 3.10 \\
\hline 10 & Protocadherin beta 9 & NM_019119 & Calcium-dependent cell-adhesion protein. & 3.00 \\
\hline 11 & $\begin{array}{l}\text { H3 histone, family } 3 A \\
\text { (H3.3A) }\end{array}$ & NM_002107.3 & Replacement histone, replication independent protein. & 2.96 \\
\hline 12 & $\begin{array}{l}\text { Thyroid hormone receptor } \\
\text { interactor } 4\end{array}$ & NM_016213 & Transcriptional coactivator of nuclear receptors. & 2.90 \\
\hline 13 & ELL associated factor 2 & NM_0I8456 & Transcriptional transactivator of ELL and ELL2 elongation activities. & 2.87 \\
\hline 14 & $\begin{array}{l}\text { RUN and SH3 domain } \\
\text { containing I }\end{array}$ & NM_0I4328 & Signaling adapter. & 2.86 \\
\hline 15 & $\begin{array}{l}\text { Cytochrome c oxidase subunit } \\
\text { Vllc }\end{array}$ & NM_001867 & Component of cytochrome c oxidase. & 2.80 \\
\hline 16 & Zinc finger protein 192 & NM_006298 & Transcriptional regulator. & 2.68 \\
\hline 17 & Notch homolog 3 & NM_000435 & Forms a transcriptional activator complex. & 2.66 \\
\hline 18 & PHD finger protein 12 & NM_00I03356I & Transcriptional repressor. & 2.65 \\
\hline 19 & GNAS complex locus (Gs $\alpha$ ) & NM_0005I6 & Guanine nucleotide-binding protein. & 2.60 \\
\hline 20 & $\begin{array}{l}\text { Nascent-polypeptide-associated } \\
\text { complex alpha polypeptide }\end{array}$ & NM_005594 & Prevents inappropriate targeting of non-secretory polypeptides to the endoplasmic reticulum. & 2.58 \\
\hline 21 & $\begin{array}{l}\text { Protein phosphatase I, catalytic } \\
\text { subunit, beta isoform }\end{array}$ & NM_002709 & Ser/Thr phosphatase, essential for cell division. & 2.55 \\
\hline 22 & $\begin{array}{l}\text { Sorbin and SH3 domain } \\
\text { containing I (SORBIN) }\end{array}$ & NM_00I034955 & Involved in insulin receptor signaling. & 2.51 \\
\hline 23 & Phosducin-like & NM_005388 & G protein modulator. & 2.51 \\
\hline 24 & $\begin{array}{l}\text { Immunoglobulin mu-binding } \\
\text { protein } 2\end{array}$ & NM_002180.I & DNA binding protein. & 2.50 \\
\hline 25 & $\begin{array}{l}\text { ornithine decarboxylase } \\
\text { antizyme I }\end{array}$ & NM_004I52 & Destabilizes and promotes degradation of ornithine decarboxylase. & 2.49 \\
\hline 26 & Septin 5 & NM_002688 & Involved in cytokinesis. & 2.44 \\
\hline 27 & epidermal growth factor & NM_001963.2 & Growth factor. & 2.40 \\
\hline 28 & Fibrosin I & NM_022452 & Fibrogenic lymphokine. & 2.31 \\
\hline 29 & $\begin{array}{l}\text { Death-associated protein kinase } \\
\text { I }\end{array}$ & NM_004938 & Pro-apoptotic calcium/calmodulin-dependent serine/threonine kinase. & 2.29 \\
\hline 30 & Caveolin 2 & NM_00I233 & $\begin{array}{l}\text { Scaffolding protein within caveolar membranes. Interacts directly with G-protein alpha subunits } \\
\text { and can functionally regulate their activity. }\end{array}$ & 2.28 \\
\hline 31 & $\begin{array}{l}\text { Dual specificity protein } \\
\text { phosphatase } 4\end{array}$ & NM_00I394 & $\begin{array}{l}\text { Regulates mitogenic signal transduction by dephosphorylating both Thr and Tyr residues on } \\
\text { MAP kinases ERKI and ERK } 2 \text {. }\end{array}$ & 2.14 \\
\hline 32 & $\begin{array}{l}\text { Brix domain-containing protein } \\
2\end{array}$ & NM_0I832I & Biogenesis of the 605 ribosomal subunit. & 2.07 \\
\hline 33 & Catenin beta (CTNNB) * & NM_0076|4.2 & Wnt signaling, cell transformation & 2.05 \\
\hline 34 & $\begin{array}{l}\text { Protein phosphatase } 2 \\
\text { (formerly 2A), catalytic } \\
\text { subunit, alpha isoform } \\
\text { (PP2ACA) }\end{array}$ & NM_0027I5 & Dephosphorylates several Ser/Thr kinases. & 2.02 \\
\hline 35 & $\begin{array}{l}\text { Heterogeneous nuclear } \\
\text { ribonucleoprotein Al } \\
\text { (hnRNPAI) }\end{array}$ & NM_002136 & RNA binding protein. & 2.00 \\
\hline
\end{tabular}

*The regulation of Catenin beta by PI3K-AKT signaling has been described elsewhere [12].

$\mathrm{B}$, three proteins implicated in cell signaling, the alpha stimulating subunit of guanine nucleotide binding pro- tein (Gs $\alpha$, encoded by the GNAS locus, GNAS), the alpha isoform of the catalytic subunit of the protein phos- 
Table 2: Transcripts whose levels are increased by at least 3 fold upon GST-KSRP chromatography when compared with control GST chromatography.

\begin{tabular}{|c|c|c|c|c|}
\hline Transcript name & Accession number & Fold enrichment & 3'UTR features & Protein functions \\
\hline RAVER2 & NM_0182II & 8.2 & II ARE pentamers & RNA-binding protein \\
\hline GNASI & NM_0005I6 & 7.7 & 2 ARE pentamers & Guanine nucleotide -binding protein \\
\hline Protein phosphatase $2 \mathrm{~A}$ catalytic subunit alpha Isoform (PP2ACA) & NM_0027I5 & 6.9 & 6 ARE pentamers & Protein phosphatase \\
\hline Sorbin and $\mathrm{SH} 3$ domain containing I (SORBIN) & NM_00I034955 & 6.5 & II ARE pentamers & Insulin signaling \\
\hline Histone $3.3 \mathrm{~A}(\mathrm{H} 3.3 \mathrm{~A})$ & NM_002107.3 & 5.9 & 7 ARE pentamers & Nucleosome formation \\
\hline hnRNPF & NM_004966 & 5.6 & 2 ARE pentamers & RNA-binding protein \\
\hline Prothymosin alpha (28) & NM_002823 & 5.5 & I ARE pentamer & Transcription factor \\
\hline hnRNPA2/BI & NM_002137 & 4.7 & 4 ARE pentamers & RNA-binding protein \\
\hline ATP synthase mitochondrial F0 complex subunit G & NM_006476 & 4.1 & 4 ARE pentamers & Mitochondrial ATPase \\
\hline$h n R N P A / B$ & M65028 & 4.0 & 3 ARE pentamers & RNA-binding protein \\
\hline hnRNPAI & NM_002136 & 4.0 & 2 ARE pentamers & RNA-binding protein \\
\hline Ecotropic viral integration site 5 & NM_005665 & 3.5 & I5 ARE pentamers & Oncogene \\
\hline Catenin beta $(\mathrm{CTNN}) *$ & NM_0076|4.2 & 3.1 & U-rich regions & Transcription/Signaling \\
\hline
\end{tabular}

*The interaction of Catenin beta mRNA with KSRP and its decay control have been described in detail elsewhere [12].

phatase 2 (PP2ACA), and the SH domain containing protein sorbin (SORBIN), as well as the replicationindependent histone H3.3A (H3.3A).

The ARE-containing regions of the novel KSRP target transcripts (Additional file 4) displayed a potent destabilizing function both in vitro (Figure 1A) and in intact cells (see below, Figure 3C). Purified recombinant KSRP was able to bind, in a dose-response manner, to the AREs of the novel KSRP targets in vitro (Figure $1 \mathrm{~B}$ ). To validate the interaction of the endogenous KSRP with its target transcripts, we performed immunoprecipitation experiments of ribonucleoprotein complexes in $\alpha \mathrm{T} 3-1$ cells. As shown in Figure $1 \mathrm{C}$, the seven transcripts were immunoprecipitated by anti-KSRP antibody as well as by anti-hnRNPA1 antibody. No KSRP target mRNA was detected in anti-AUF1 immunoprecipitates under standard experimental conditions (Figure 1C). However, when the amount of cDNAs obtained by retrotranscription and used in PCR reactions was increased by 10-fold, bands corresponding to hnRNPA/B and prothymosin $\alpha$ (PTMA) mRNAs (both already identified as AUF1 targets [17]) were detected (Additional file 5). Interestingly, also anti-HuR antibody immunoprecipitated the KSRP target mRNAs while antiTTP antibody immunoprecipitated only hnRNPF and GNAS (Figure 1C) as well as GM-CSF mRNA which is a typical TTP target transcript (data not shown). We obtained similar results performing immunoprecipitation of ribonucleoprotein complexes in $\mathrm{C} 2 \mathrm{C} 12$ myoblasts (data not shown).

\section{KSRP associates with AUFIp45 and hnRNPAI in the cytoplasm of $\alpha$ T3-I cells}

HPLC gel filtration of S100 extracts from $\alpha \mathrm{T} 3-1$ cells followed by anti-KSRP immunoblotting analysis, showed that KSRP is present in fractions of molecular mass ranging from $150 \mathrm{KDa}$ to over-440 KDa (Figure 2A, top panel). We have previously demonstrated that KSRP functionally associates with components of the mRNA decay machinery $[7,9,18]$. In order to identify KSRP molecular partners additional to those already known, a yeast two-hybrid screening using KSRP as a bait was performed. We identified several potential KSRP interacting proteins (listed in Table 3) including the chaperone protein 14-3-3 $\zeta$ whose function in KSRP-dependent $\beta$-catenin mRNA decay was recently described by Gherzi et al. [12]. We found, among others, the cDNAs encoding two bona fide ARE binding proteins, the p45 isoform of AUF1 (AUF1p45) [6] and hnRNPA1 [19]. Both AUF1p45 and hnRNPA1 elute together with KSRP in gel filtration fractions ranging from 100 to $200 \mathrm{KDa}$ (Figure 2A, middle and bottom panels and data not shown). The interaction of either AUF1p45 or hnRNPA1 with KSRP was confirmed by anti-KSRP immunoprecipitation of RNase A-treated $\alpha \mathrm{T} 3-1$ cytoplasmic extracts followed by either anti-AUF1 or antihnRNPA1 immunoblotting (Figure 2B). GST-fused KSRP was able to pull-down both endogenous AUF1p45 and hnRNPA1 from $\alpha \mathrm{T} 3-1$ cytoplasmic extracts (Figure 2C). These data, together with those presented in Figure 1C suggest that KSRP target transcripts belong to a ribonucleoprotein complex including AUF1p45 and hnRNPA1.

We investigated whether either AUF1p45 or hnRNPA1 or both directly interacted with KSRP target transcripts. UVcrosslinking experiments failed to display high affinity interaction of these ARE-BPs with the KSRP target transcripts in vitro (data not shown). This finding suggest that AUF1p45 and hnRNPA1 are part of the KSRP-containing ribonucleoprotein complex but do not directly interact with KSRP targets.

\section{KSRP knock-down in $\alpha$ T3-I cells stabilizes KSRP target transcripts}

To verify the relevance of KSRP in the decay control of its target transcripts, stable knock-down of KSRP using a short-hairpin vector was performed in $\alpha$ T3-1 cells ( $\alpha \mathrm{T} 3-1$ - 


\section{A}

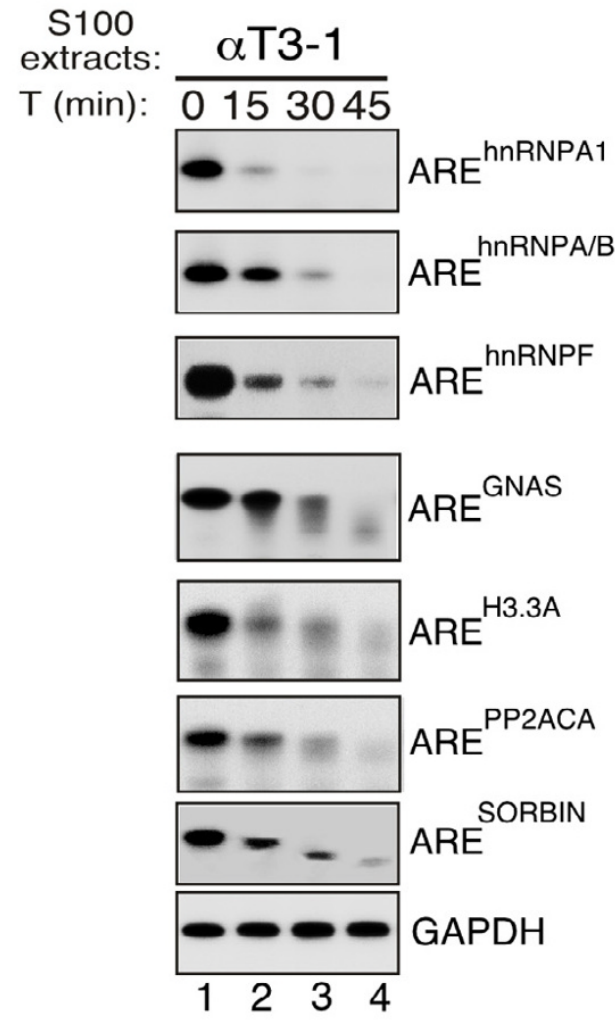

B
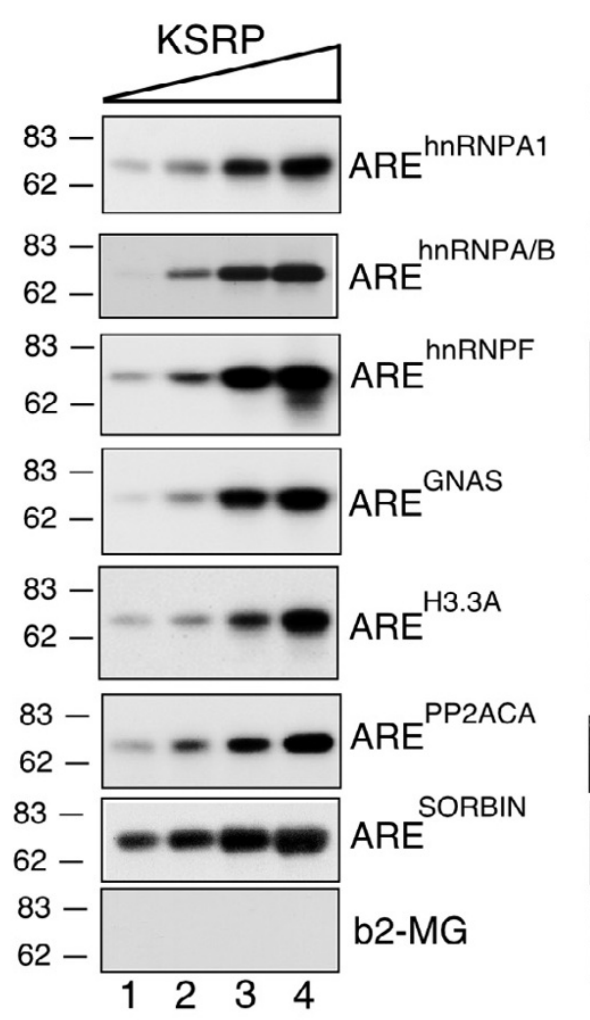

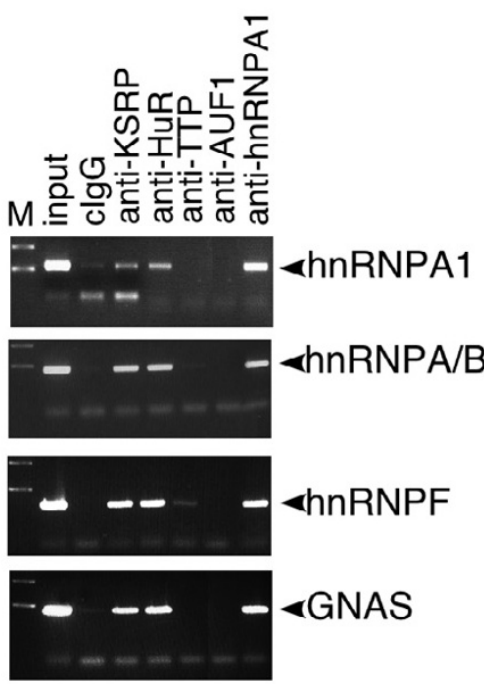

C

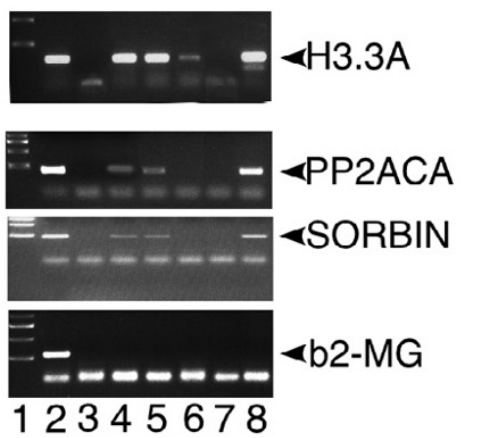

\section{Figure I}

KSRP associates with a set of unstable mRNAs overrepresented in myrAKTI- $\alpha$ T3-I cells. (A) In vitro RNA degradation assays

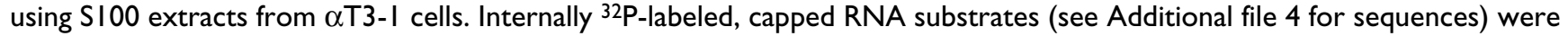
incubated with extracts for the indicated times and their decay analyzed as described in Methods. (B) The interaction between 32P-labeled RNAs (indicated on the right) and recombinant purified KSRP (30-300 nM) was evaluated by UV-crosslinking. (C) Immunoprecipitation of ribonucleoprotein complexes containing different KSRP target mRNAs. The proteins were immunoprecipitated from $\alpha \mathrm{T} 3-\mathrm{I}$ cell extracts using the indicated antibodies. RNA was extracted from the immune complexes and analyzed by RT-PCR as described in Methods.

shKSRP; Figure 3A). KSRP knock-down led to two- to fivefold increase of the steady-state levels of KSRP target mRNAs in $\alpha$ T3-1-shKSRP when compared to mock-transfected cells (Figure $3 \mathrm{~B}$ ). No changes were seen with the control $\beta 2-M G$ RNA levels (Figure 3B). Next, using actinomycin $\mathrm{D}$, we analyzed the $\mathrm{t} 1 / 2$ of the identified KSRP target mRNAs in both mock- $\alpha \mathrm{T} 3-1$ and $\alpha \mathrm{T} 3-1$-shKSRP cells. Results presented in Figure 3C showed that KSRP knockdown in $\alpha \mathrm{T} 3-1$ cells strongly increased the $\mathrm{t} 1 / 2$ of all the transcripts (from less than $60 \mathrm{~min}$. in mock- $\alpha \mathrm{T} 3-1$ to more than 2 hours in $\alpha \mathrm{T} 3-1$-shKSRP cells, see Additional file 6).
Overall these data indicate that KSRP interacts with a subset of mRNAs up-regulated in cells expressing constitutively active AKT1 and regulates their stability and steadystate levels in $\alpha \mathrm{T} 3-1$ cells.

\section{PI3K-AKT activation stabilizes KSRP target transcripts}

We recently showed that PI3K-AKT activation in $\alpha \mathrm{T} 3-1$ cells stabilizes $\beta$-catenin mRNA and induces its accumulation [12]. These events are mediated by KSRP phosphorylation and functional inactivation [12]. To investigate whether the activation of the pathway affects the stability of the novel KSRP targets, we took advantage of $\alpha \mathrm{T} 3-1$ myrAKT1 cells [12]. As shown in Figure 4A, the kinase 

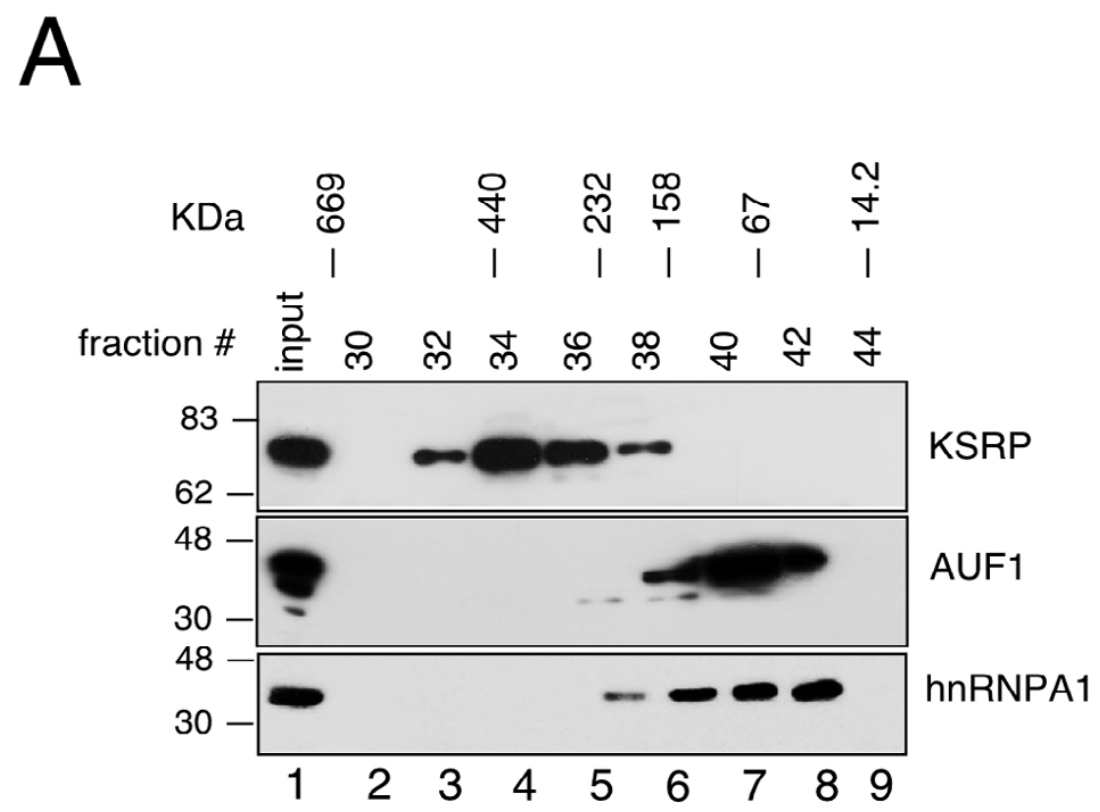
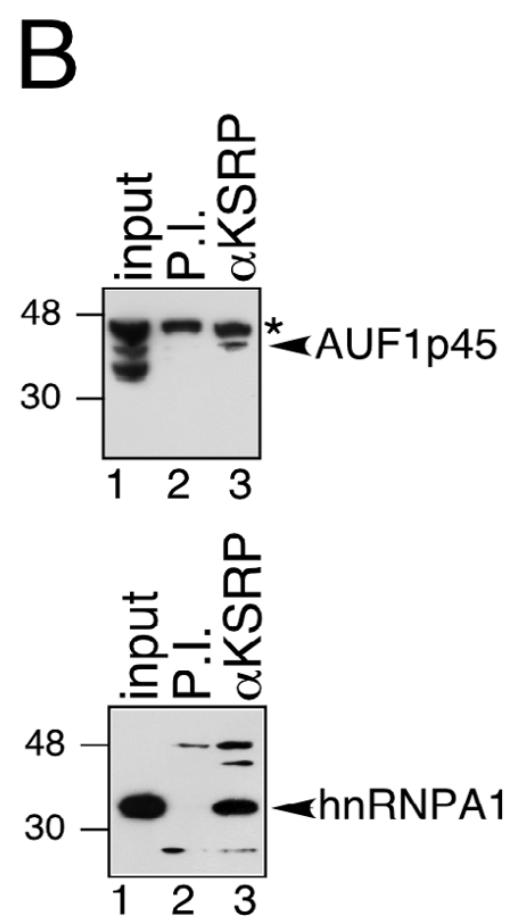
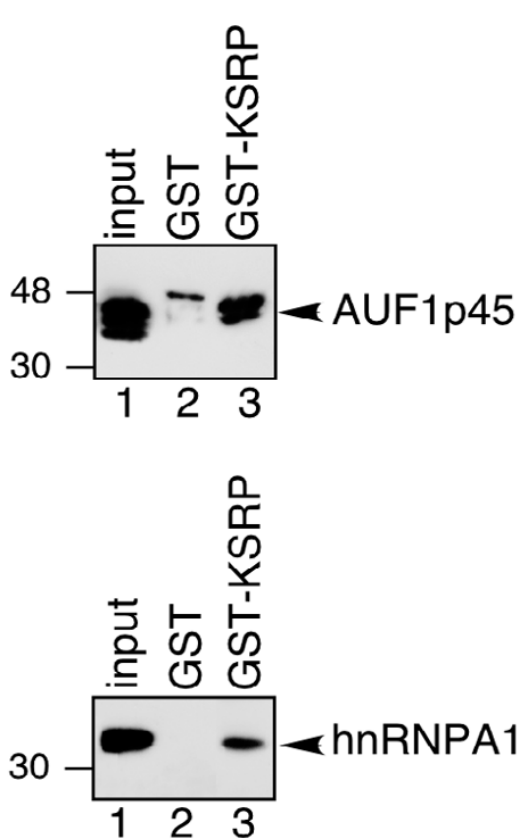

\section{Figure 2}

KSRP associates with AUFIP45 and hnRNPAI in cytoplasmic extracts of aT3-I cells. (A) SI00 extracts from $\alpha$ T3-I cells were subjected to gel filtration chromatography on a Superose 6 column. Aliquots of the eluted fractions were analyzed by Western blotting using the indicated antibodies. (B) RNase A-treated SI 00 extracts from $\alpha \mathrm{T} 3-\mathrm{I}$ cells were immunoprecipitated with preimmune (lane 2) or anti-KSRP (lane 3) sera and analyzed by immunoblotting with either anti-AUFI (top) or anti-HnRNPAI (bottom) antibodies. The arrows mark the position of either AUFIp45 or hnRNPAI, while the asterisk marks a anti-AUFI cross-reacting band. (C) GST-pulldown of either endogenous AUFIp45 (top) or endogenous hnRNPAI (bottom) from SI00 extracts of $\alpha$ T3-I cells using either control GST or GST-KSRP. Proteins were analyzed by immunoblotting using the indicated antibodies. The arrows mark the position of either AUFIp45 or hnRNPAI. 
A

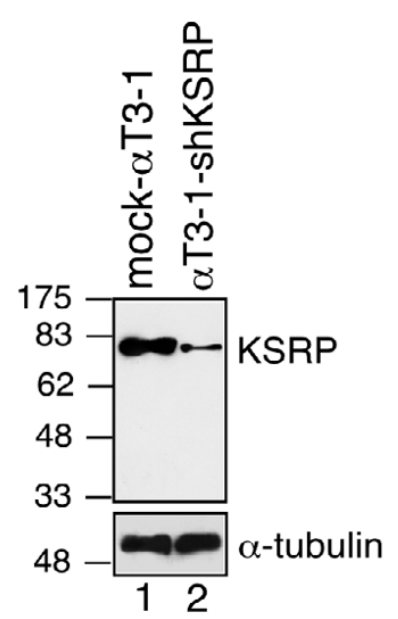

C
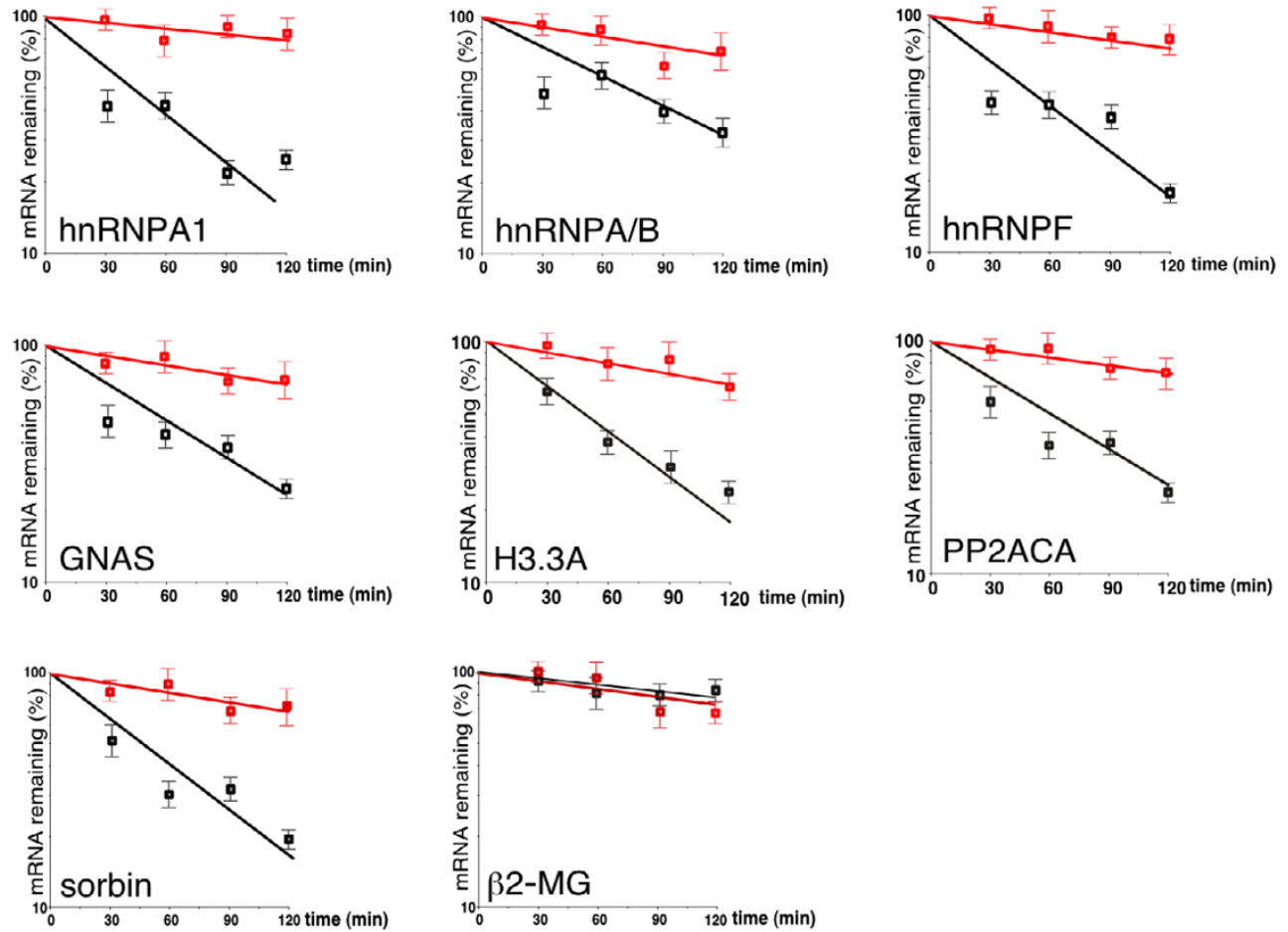
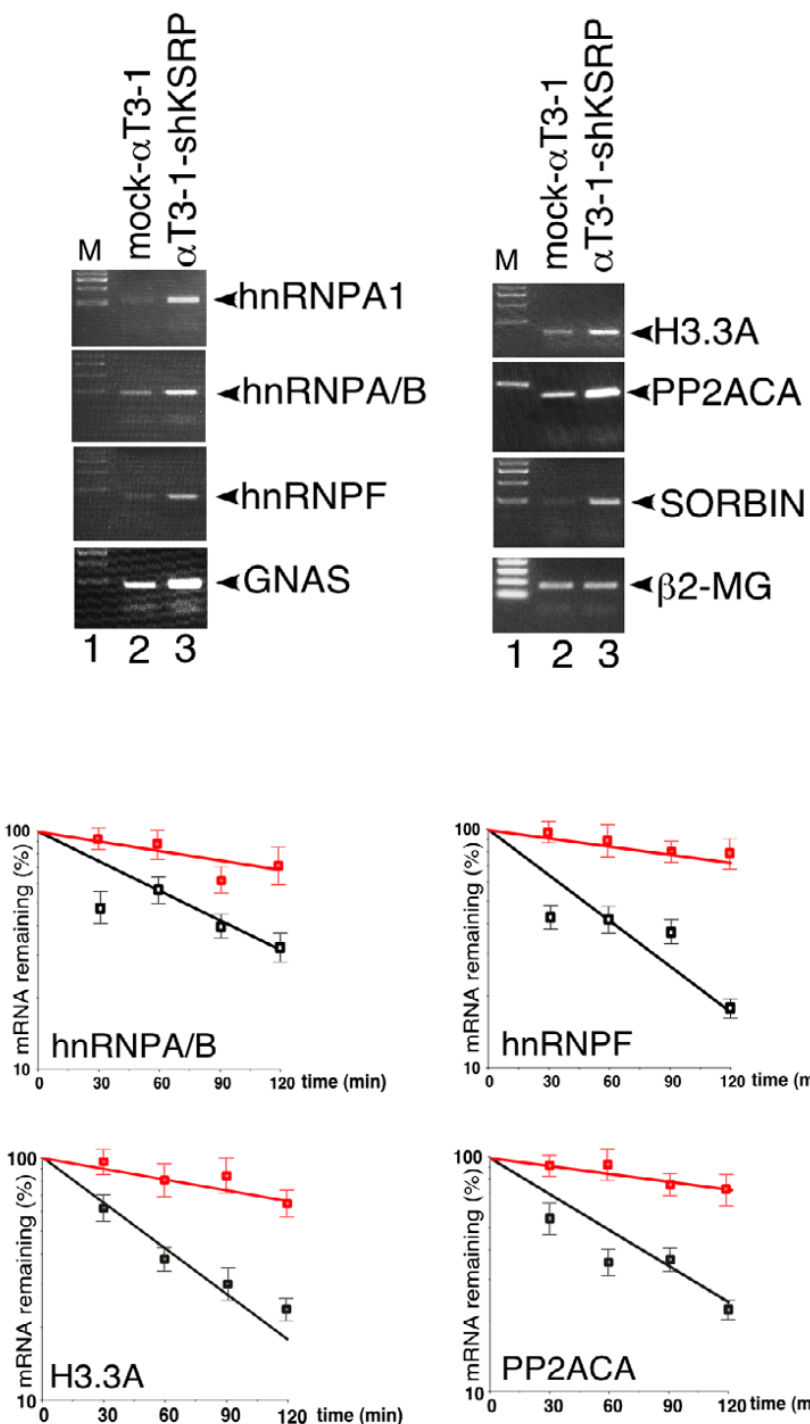

123

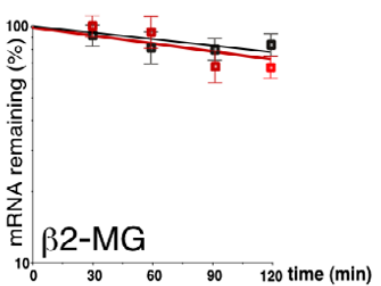

Figure 3

KSRP is required for rapid degradation of a set of unstabletranscripts. (A) Immunoblot analysis of total extracts from either mock- $\alpha$ T3-I (empty PSUPER-Puro vector-transfected) or $\alpha$ T3-I-shKSRP (pSUPER-Puro-shKSRP-transfected) cells using affinity-purified anti-KSRP and anti- $\alpha$-tubulin antibodies. (B) Expression of a set of KSRP-interacting mRNAs and $\beta 2-M G$ (as a control), monitored by RT-PCR, in either mock- $\alpha$ T3-I, or $\alpha$ T3-I-shKSRP cells. (C) Semi quantitative RT-PCR analysis of both labile KSRP-associated mRNAs and $\beta 2-M G$ mRNA in either mock- $\alpha$ T3-I (black lines), or $\alpha$ T3-I-shKSRP cells (red lines). Total RNA was isolated at the indicated times after addition of Actinomycin $D$. The amount of each transcript was quantitated by densitometry and plotted using a linear regression program. The values shown are averages ( \pm SEM) of three independent experiments performed in duplicates. A quantitation of the transcripts' $t(I / 2)$ is presented in Additional file 6. 
Table 3: Molecular partners of KSRP identified by two-hybrid screening.

\begin{tabular}{lll}
\hline Protein name & Protein function & Accession number \\
\hline hnRNP-AI & RNA binding protein & P493I2 \\
hnRNP-A/B & RNA RNA binding protein & NP_034578 \\
AUFI P45 & ARE binding protein & NP_03I542 \\
PABPNI & Poly $(A)$ binding protein & XP_214I72 \\
elF2B beta subunit & Translation factor & NP_663420 \\
I4-3-3 $\zeta$ & Molecular chaperone & NP_035870 \\
\hline
\end{tabular}

activity immunoprecipitated with anti-AKT antibody was $\sim 5$ fold higher in $\alpha$ T3-1-myrAKT1 than in mock- $\alpha$ T3-1 cells thus demonstrating that active AKT kinase was present in $\alpha \mathrm{T} 3-1$ cells expressing myrAKT1. The steadystate levels of KSRP target mRNAs were increased by 2.5-4 fold in intact $\alpha$ T3-1-myrAKT1 cells (Figures 4B). In addition, the $\mathrm{t} 1 / 2$ of the KSRP mRNA targets was prolonged above 2 hours as a result of AKT1 activation in $\alpha \mathrm{T} 3-1$ myrAKT1 cells (Figures 4C and Additional file 7).

Since PI3K-AKT signaling is known to be physiologically activated by insulin treatment [[12], and literature cited therein], we investigated the effect of insulin treatment on the decay rates of KSRP target transcripts. Insulin treatment of insulin receptor overexpressing HIRc-B cells produced a strong activation of immunoprecipitated AKT activity (Figure 5A) and caused stabilization of KSRP targets in vitro (Figure 5B).

Notably, both the $1 / 2$ and steady-state levels of some of the KSRP targets (Table 2), as exemplified by PTMA, were not affected by PI3K-AKT activation although increased by KSRP knock-down in $\alpha \mathrm{T} 3-1$ cells (Additional file 8).

Altogether, these data indicate that activation of PI3K-AKT signaling increased both the $\mathrm{t} 1 / 2$ and the steady-state levels of a subset of KSRP target transcripts.

\section{Discussion}

Here we report that KSRP controls the half-life and the steady-state levels of a set of unanticipated labile mRNAs in $\alpha \mathrm{T} 3-1$ cells. The expression and the stability of the majority of these KSRP target transcripts is increased upon activation of PI3K-AKT signaling. Furthermore, we show that KSRP forms a ribonucleoprotein complex together with its target transcripts and the RNA binding protein hnRNPA1.

Recently, we have shown that activation of PI3K-AKT pathway induces KSRP-controlled regulation of $\beta$-catenin mRNA in $\alpha \mathrm{T} 3-1$ cells [12]. We hypothesized that PI3KAKT activation could prolong the $1 / 2$ of ARE-containing mRNAs additional to $\beta$-catenin by targeting KSRP.
In order to identify transcripts whose $1 / 2$ and steady-state levels are controlled by KSRP and respond to PI3K-AKT activation, we performed a comparative analysis of the AU-rich transcriptome of $\alpha \mathrm{T} 3-1$ cells focusing our attention onto KSRP target transcripts which are overrepresented in cells expressing a constitutively active AKT1. Microarray-based methods have been successfully used to study global patterns of transcript decay and comprehensively identify targets of RNA-binding proteins thus providing unique insights into gene expression programs $[17,20-25]$. We identified a set of mRNAs that interact with KSRP and whose $1 / 2$ and steady-state levels are consistently increased by either KSRP knock-down or PI3KAKT activation. Among these transcripts, three encode RNA binding proteins mainly implicated in pre-mRNA splicing events (hnRNPA1, hnRNPF, and hnRNPA/B), three encode signaling molecules (Gs $\alpha$, PP2ACA, SORBIN), and one encodes the replication-independent histone H3.3A. To our best knowledge, none of these transcripts has been yet reported to undergo posttranscriptional control of its expression through regulation of mRNA decay rates.

Our present data (see Additional file 2) together with our previous observations [7,10-12] indicate that KSRP interacts with a rather broad array of ARE-like sequences. The criteria used by KSRP to recognize its RNA targets remain still unknown, and to date there are no reports that provide an explanation for its target recognition at the molecular level. Our unpublished structural studies on KSRP domains (M.F. Garcia-Mayoral et al., submitted) show a modularity of the interaction between K-homology (KH) domains 3 and 4 that can increase the adaptability to different RNA sequences/structures thus providing a possible explanation for the ability of KSRP to recognize highly heterogeneous RNA targets. These data indicate that KH3 and $\mathrm{KH} 4$ can adapt to different AU-rich sequences within the ARE without being limited by a rigid, pre-existing protein-protein interaction (M.F. Garcia-Mayoral et al., submitted). This provides the protein with a flexible recognition unit than can adapt to different RNA sequences and can mediate interactions in the structural environment of different 3'UTRs. 


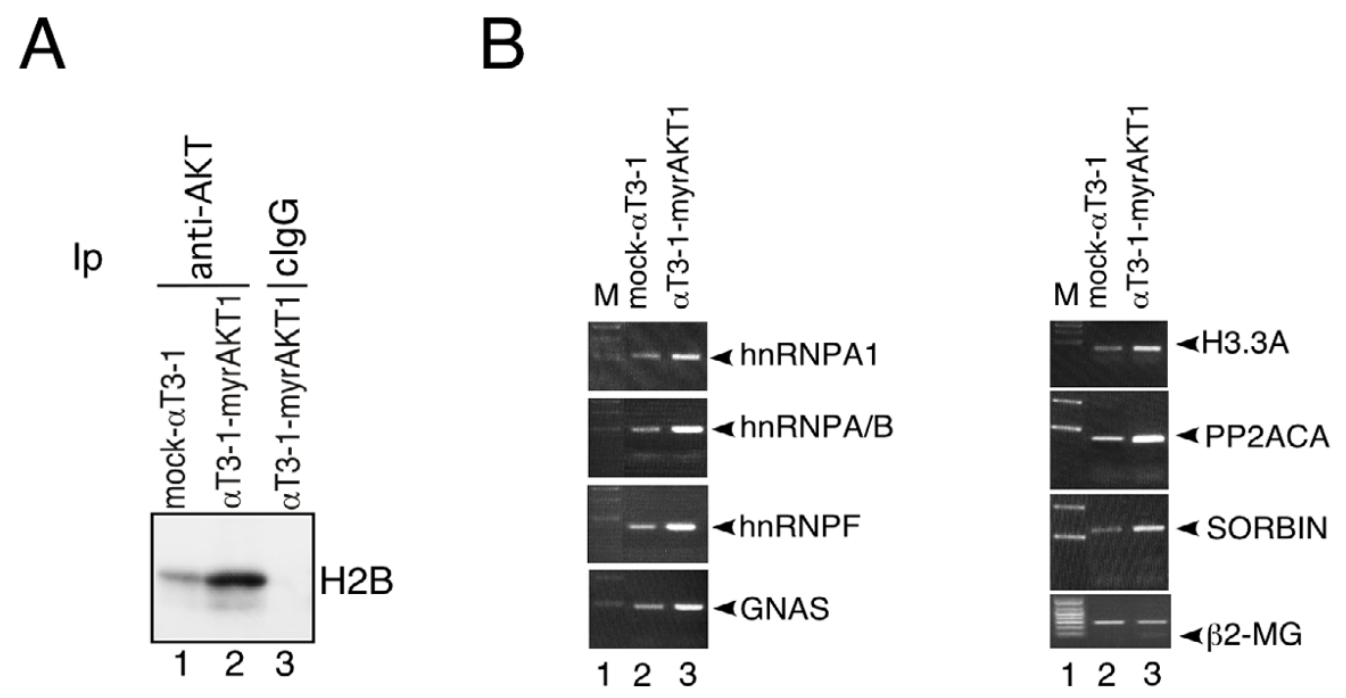

C
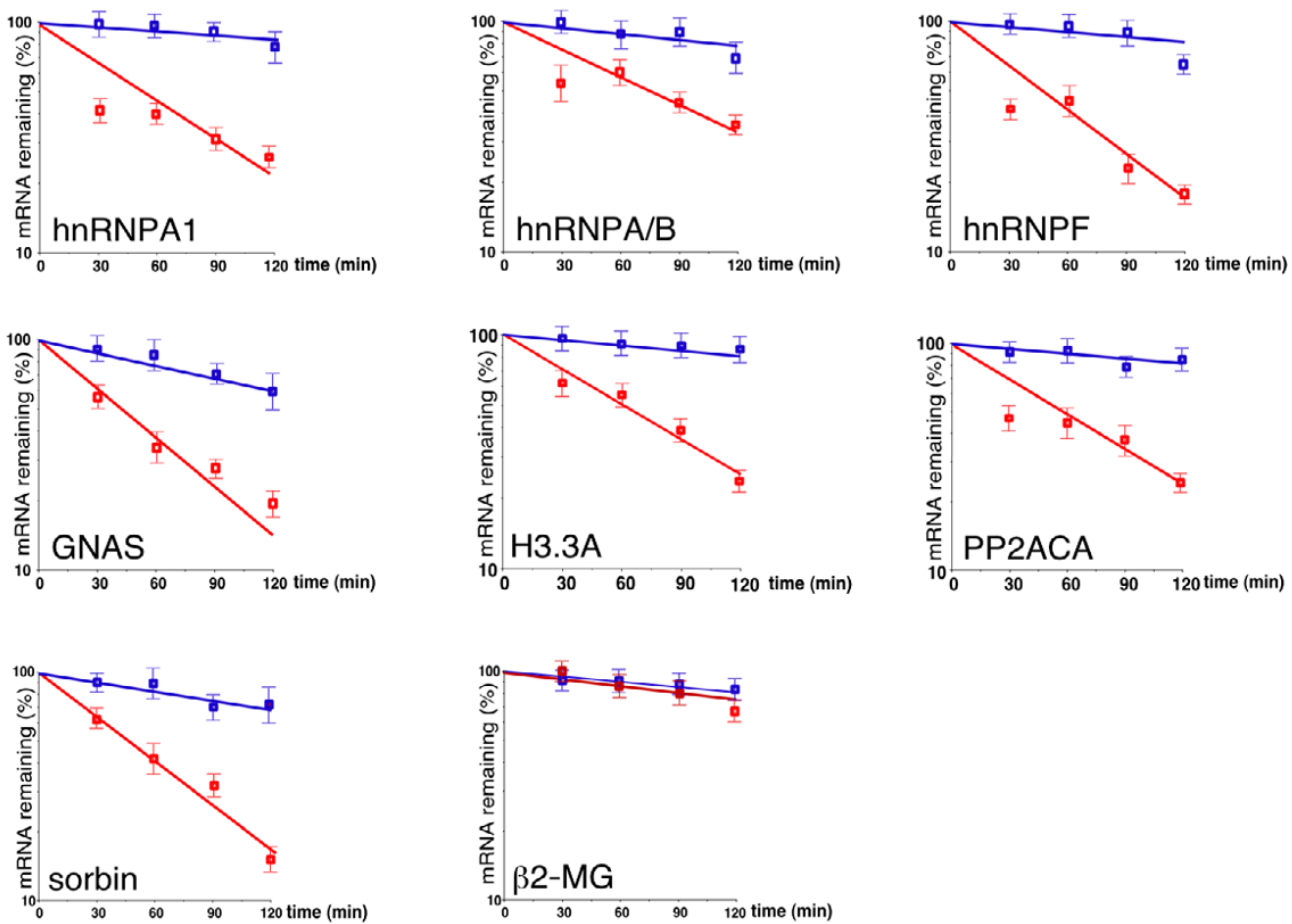

Figure 4

PI3K-AKT signaling stabilizes a set of KSRP-interacting mRNAs and increases their expression. (A) Either mock- $\alpha$ T3-I or $\alpha$ T3I-myrAKTI cells were lysed and total extracts were immunoprecipitated (IP) with either anti-AKT antibody or control IgG (clgG). Pellets were incubated $\left(20 \mathrm{~min}\right.$ at $\left.30^{\circ} \mathrm{C}\right)$ with histone $2 \mathrm{~B}(\mathrm{H} 2 \mathrm{~B})$ in kinase buffer in the presence of $\gamma\left[{ }^{32} \mathrm{P}\right] \mathrm{ATP}$ under gentle shaking. Labeled proteins were separated by SDS-PAGE and detected by autoradiography. (B) Expression of KSRP-interacting mRNAs and $\beta 2-M G$ (control transcript), monitored by RT-PCR, in either mock- $\alpha$ T3-I or $\alpha$ T3-I-myrAKTI cells. (C) Semi quantitative RT-PCR analysis of both KSRP-interacting mRNAs and $\beta 2-M G$ (control transcript) in either mock- $\alpha$ T3-I (red lines) or $\alpha$ T3-I-myrAKTI (blue lines). Total RNA was isolated at the indicated times after addition of Actinomycin D. The amount of each transcript was quantitated by densitometry and plotted using a linear regression program. The values shown are averages $( \pm$ SEM) of three independent experiments performed in duplicates. A quantitation of the transcripts' $t(I / 2)$ is presented in Additional file 7. 


\section{A}

B

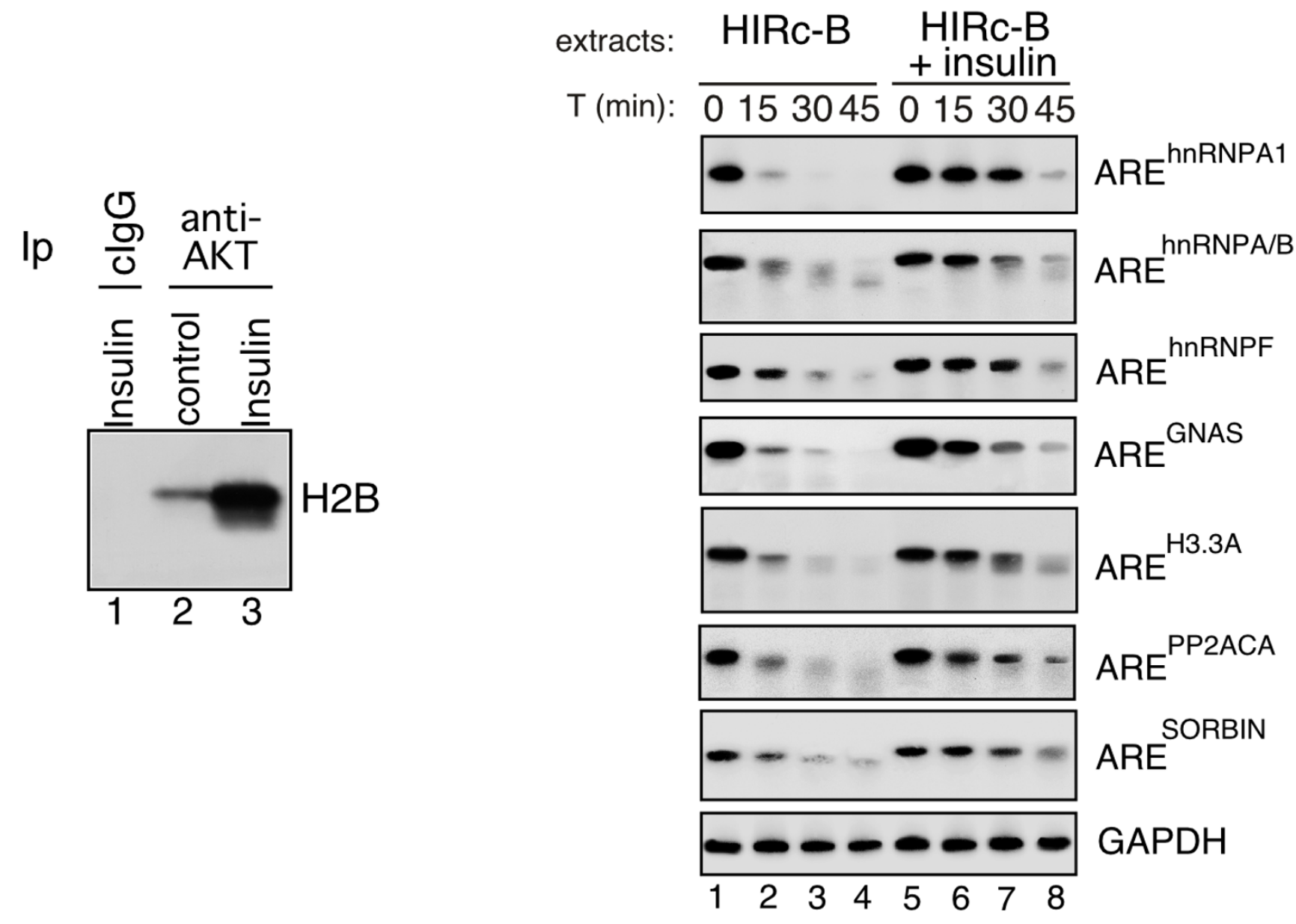

Figure 5

Insulin stabilizes a set of KSRP-interacting mRNAs. (A) Serum-starved HIRc-B cells were treated for I h with either PBS (control) or insulin $\left(10^{-6} \mathrm{M}\right)$. Total extracts were immunoprecipitated with either anti-AKT antibody or control lgG (clgG). Pellets were incubated $\left(20 \mathrm{~min}\right.$ at $\left.30^{\circ} \mathrm{C}\right)$ with histone $2 \mathrm{~B}(\mathrm{H} 2 \mathrm{~B})$ in kinase buffer in the presence of $\gamma\left[{ }^{32} \mathrm{P}\right] \mathrm{ATP}$ under gentle shaking. Labeled proteins were separated by SDS-PAGE and detected by autoradiography. (B) In vitro RNA degradation assays using SIO0 extracts from either control or insulin ( $10^{-6} \mathrm{M}$ )-treated HIRc-B cells. Internally ${ }^{32} \mathrm{P}$-labeled, capped RNA substrates (see Additional file 4 for sequences) were incubated with S100 extracts for the indicated times and their decay analyzed as described in Methods.

PI3K-AKT signaling has been reported to cause phosphorylation and activation of the SR-family members of splicing factors $[26,27]$. Interestingly, hnRNPA1 has been shown to antagonize the splicing activity of SR proteins [28]. Increased expression of hnRNPA1 could be viewed as a mean by which PI3K-AKT signaling finely modulates select splicing events. Intriguingly, hnRNPA1 transcript interacts with KSRP in the context of a complex that includes hnRNPA1 protein, thus suggesting the existence of an auto-regulatory loop.
GNAS gene encodes the Gs $\alpha$ that is required for hormonestimulated cAMP generation [29]. Recently, Chen et al. demonstrated that GNAS gene deletion causes increased insulin sensitivity targeting AKT [30]. Our data allow the hypothesis that AKT could, in turn, regulate Gs $\alpha$ expression and activity operating a negative feed back-control on insulin responsiveness.

Protein phosphatase 2A (PP2A) comprises a family of serine/threonine phosphatases, whose minimal component 
is a well conserved catalytic subunit [reviewed in [31]]. PP2A plays a prominent role in cell cycle regulation, cell morphology and development [31]. We have recently shown that PI3K-AKT activation increases the expression of $\beta$-catenin by prolonging its mRNA $t(1 / 2)$ through functional inactivation of KSRP. Intriguingly, PP2A can dephosphorylate $\beta$-catenin thus preventing its degradation and, therefore, it has been proposed as an activator of $\beta$ catenin signaling $[32,33]$. Therefore PI3K-AKT, inducing stabilization of the two KSRP target transcripts $\beta$-catenin and PP2ACA, could enhance the cellular levels of $\beta$-catenin protein operating a combinatorial positive control. On the other hand, either inhibition or disruption of PP2A complexes leads to AKT activation [31]. Therefore, it is possible that PP2ACA mRNA stabilization and enhanced expression could operate a negative feed-back on the effects of either exaggerate or inappropriate PI3KAKT signaling activation [34]. A potential model for KSRP-mediated control of PI3K-AKT/ $\beta$-catenin signaling is presented in Additional file 9.

SORBS1, the human gene that encodes SORBIN, was mapped to the locus which is a candidate region for insulin resistance found in Pima Indians [35]. CAP, the mouse homologue of SORBIN, is a cytoskeletal adaptor protein involved in modulating adhesion-mediated signaling events that lead to cell migration [36]. It has been shown that stable cell lines overexpressing CAP exhibit a reduced growth rate [37]. Recently, Katsanakis and Pillay showed that AKT phosphorylates the APS protein, a key factor in the signaling events that involve CAP [38]. Our data support the existence of an additional point of cross-talk between PI3K-AKT signaling and the SORBIN/CAP pathway in insulin signaling.

Variations in the expression of histone H3.3A, a cell cycleindependent replacement histone, during differentiation of murine erithroleukemia cells, has been hypothesized to depend on post-transcriptional regulatory events [39]. Although histone H3.3A expression regulation has not been reported to be controlled by PI3K-AKT signaling, it has been correlated to cell transformation and differentiation $[40,41]$.

Further investigations will be necessary to elucidate the functional role, if any, of the coordinated decay control of the identified transcripts by PI3K-AKT signaling under different physiological and pathological conditions.

Our data indicate that KSRP interacts with AUF1p45 and hnRNPA1 in the cytoplasm of $\alpha \mathrm{T} 3-1$ cells. Only one of the PI3K-AKT-regulated KSRP targets, hnRNPA/B, is very weakly immunoprecipitated by anti-AUF1 antibody (Figure 1C and Additional file 5). Conversely, anti-hnRNPA1 antibody efficiently immunoprecipitates KSRP target tran- scripts (Figure 1C). Both AUF1p45 and hnRNPA1 bind very weakly to the same RNAs in vitro (data not shown). hnRNPA1 has been implicated in many aspects of mRNA maturation, transport, turnover and in telomere and telomerase regulation $[42,43]$. Hamilton et al. [19] reported that hnRNPA1 interacts with ARE-containing mRNAs and suggested a role for this factor in ARE-mediated decay. Our findings allow to hypothesize that AUF1p45 and hnRNPA1 play some, yet unidentified, regulatory role in the ribonucleoprotein complex that includes KSRP and its target transcripts. We can hypothesize that, in response to certain stimuli, the two KSRP-interacting ARE-BPs could acquire high affinity binding for target mRNAs thus either potentiating or terminating the decay-promoting activity of KSRP on the same transcripts.

The mRNA stability promoting factor HuR interacts with KSRP target transcripts both in vitro (data not shown) and in intact cells (Figure 1C). We have previously reported that the balanced interaction of KSRP and HuR to common sets of transcripts could allow a fine tuning of mRNA decay regulation upon specific stimuli $[10,11]$. Similar results were obtained by Linker et al. [13]. Our present data further support the idea that complex interactions in the ARE-BP network are required to ensure accurate regulation of the $\mathrm{t} 1 / 2$ of select transcripts.

\section{Conclusion}

In conclusion, we have identified several KSRP target mRNAs that are overrepresented upon activation of PI3KAKT signaling. The interaction of KSRP with these transcripts was validated in vitro and in intact cells. Importantly, both KSRP knock-down and PI3K-AKT activation were found to increase the stability and the steady-state levels of these target mRNAs. Our findings provide comprehensive and valuable insight into the KSRP-containing ribonucleoprotein complexes that govern gene expression at the posttranscriptional level.

\section{Methods}

\section{Yeast two hybrid screening}

A cDNA fragment encoding amino acids 47-711 of human KSRP was cloned into pDBLeu vector (Invitrogen) and used as the bait. MaV203 yeast cells containing pDBLeu-KSRP constructs were tested for self-activation and the concentration of 3-Amino-1,2,3,-Triazole required to inhibit the basal endogenous expression of HIS3 gene was determined. A e12.5 mouse embryo head cDNA library was prepared using the pEXP-AD502 vector according to manufacturer's (Invitrogen) instructions. pDBLeu-KSRPcontaining MaV203 yeast cells were transfected with the library and selected according to the activation of the three reporter genes HIS3, URA3 and LacZ according to the manufacturer's (Invitrogen) protocol. 


\section{Isolation of KSRP-co-purifying RNAs}

To isolate mRNAs co-purifying with KSRP, the SNAAP (isolation of specific nucleic acids associated with proteins) technique described by Trifillis et al. [16] was used with minor modifications. Briefly, both GST and GSTKSRP fusion protein were expressed in Escherichia coli BL21. Cells expressing either protein were resuspended in lysis buffer (20 mM HEPES, pH 7.6, $1.5 \mathrm{mM} \mathrm{MgCl}_{2}, 10$ $\mathrm{mM} \mathrm{KCl}, 0.5 \mathrm{mM}$ DTT, 1X Complete protease inhibitors (Roche)), disrupted by sonication, and insoluble material removed by centrifugation. To eliminate bacterial RNAs, the extract was treated with $200 \mathrm{U} / \mathrm{ml}$ micrococcal nuclease (GE Healthcare) in the presence of $1 \mathrm{mM} \mathrm{CaCl}_{2}$ at 30 $\mathrm{C}$ for $20 \mathrm{~min}$, and the reaction was stopped with the addition of $5 \mathrm{mM}$ ethylene glycol bis(2-aminoethyl ether)$\mathrm{N}, \mathrm{N}, \mathrm{N}$ 'N'-tetraacetic acid (EGTA). Approximately $4 \mathrm{mg}$ of either GST or GST-KSRP were bound to $1 \mathrm{ml}$ GST-beads in a total volume of $5 \mathrm{ml}$ in RNA binding buffer (RBB; 10 $\mathrm{mM}$ Hepes, $\mathrm{pH}$ 7.6, $3.0 \mathrm{mM} \mathrm{MgCl}, 100 \mathrm{mM} \mathrm{KCl}, 2 \mathrm{mM}$ DTT, 5\% glycerol, $0.5 \%$ Triton X-100, 1X Complete) at $4^{\circ} \mathrm{C}$ for $1 \mathrm{~h}$. Unbound proteins were removed with ten 5 $\mathrm{ml}$ washes in RBB. The washed beads were resuspended in $5 \mathrm{ml}$ of RBB containing $50 \mu \mathrm{g} / \mathrm{ml}$ heparin (Calbiochem) and $200 \mathrm{U} / \mathrm{ml}$ RNasin (Promega). Fifty mg of cytoplasmic S100 extracts from $\alpha \mathrm{T} 3-1$ cells were precleared with $2 \mathrm{ml}$ of glutathione Sepharose slurry (extensively washed in $\mathrm{RBB})$ to remove background RNAs that bind to the glutathione Sepharose beads. Incubation of the precleared S100 extracts to the above described washed beads was carried out at $4^{\circ} \mathrm{C}$ for $1 \mathrm{~h}$ under rotation, followed by six 5-ml washes in RBB. The RNA was then extracted with phenol/chloroform (1:1) and chloroform, ethanol precipitated with GlycoBlue (Ambion), and washed with 70\% EtOH. The dried RNA was resuspended in $50 \mu \mathrm{l}$ DEPCtreated $\mathrm{H}_{2} \mathrm{O}$.

\section{Microarray hybridization and computational analysis of AREs}

The glass microarrays contained cDNA probes representing more than 3000 ARE-cDNAs and control clones (their identities were obtained from AU-rich element-containing mRNA database ARED 3.0 [2]). The microarrays were hybridized with cDNA generated from total RNA $(15 \mu \mathrm{g})$ and labeled with either Cy5 or Cy3 (control). The utilized hybridization protocol (Genisphere kit, Genisphere, Inc., Hatfield, PA) eliminated the possibility of signal contribution from genomic DNA [15]. cDNA microarrays scanning, pre-processing, filtering of erroneous signals, and normalization were performed as described in [15].

314 mRNAs enriched by at least 1.8-fold in KSRP-bound RNA samples (KSRP targets) and 314 mRNAs that were not enriched in KSRP-bound RNA samples (non-KSRP targets) were extracted from the microarray data. The sequences of the 3' UTR of both groups were used as input for the MotifSampler algorithm. The MotifSampler algorithms finds over-represented motifs in sequence regions using Gibbs sampling that has been successfully applied for both promoter and unstranslated regions [44]. This strategy has been applied previously [45].

\section{Cells, transfections}

Murine $\alpha \mathrm{T} 3-1$ pituitary cells and rat HIRc-B fibroblasts were cultured in DMEM plus 10\% FBS. $\alpha$ T3-1 cell transfections were performed using Lipofectamine Plus (Invitrogen), G418 (Invitrogen) was used at $500 \mu \mathrm{g} / \mathrm{ml}$ for selection. Cell pools of transfectants were used for experiments. Both mock- $\alpha \mathrm{T} 3-1$ and $\alpha \mathrm{T} 3-1-\mathrm{myrAKT} 1$ cells were starved in DMEM plus $0.5 \%$ FBS for 16 hrs prior to experiments. HIRc-B cells were starved in DMEM plus 0.1\% FBS for 16 hrs prior to experiments or further treatments.

\section{shRNA-mediated KSRP knock-down}

pSUPER-Puro-shKSRP was previously described [11]. $\alpha$ T3-1 cells were transfected using Lipofectamine Plus (Invitrogen). Transfectant pools were selected with $0.3 \mu \mathrm{g} /$ $\mathrm{ml}$ puromycin (Sigma).

\section{Recombinant proteins and antibodies}

Affinity-purified human KSRP, expressed using the Baculovirus system, was described in Briata et al. [11]. cDNA fragments encoding the entire coding sequence of human hnRNPA1, the entire coding sequence of murine AUF1p45, and nt. 202-2136 of human KSRP were cloned into the pGEX6 to generate GST-A1, GST-AUF1p45, and GST-KSRP respectively. E. Coli-expressed GST-A1 protein was digested by Prescission protease (GE Healthcare) according to manufacturer's instructions. Anti-KSRP rabbit polyclonal antibody was previously [7] described. Anti-AUF1 and anti-hnRNP-A1 monoclonal antibodies were a kind gift from Dr. Gideon Dreyfuss. Anti-TTP (rabbit polyclonal H-120) was from Santa Cruz. Anti- $\alpha$-tubulin, and anti HuR (3A2) monoclonal antibodies were from Sigma and Santa Cruz, respectively.

\section{RNA in vitro degradation and UV crosslinking}

${ }^{32} \mathrm{P}$-labeled RNAs were synthesized and used as substrates for in vitro degradation assays as reported [46]. UVcrosslinking experiments were performed as described [46].

\section{Immunoprecipitation of ribonucleoprotein complexes}

Ribonucleoprotein complexes were immunoprecipitated from $\alpha$ T3-1 cell lysates as previously described [46]. Total RNA, extracted from either immunocomplexes or total cell lysates (input) was subjected to RT-PCR reactions. Primers are listed in Additional file 10. 


\section{In vitro kinase assays}

Kinase assays were performed using AKT kinase activity immunoprecipitated from cell lysated and histone $\mathrm{H} 2$ (Roche) as the substrate. $\left[\gamma^{32} \mathrm{P}\right]$ ATP $(3000 \mathrm{Ci} / \mathrm{mmol})$ was from GE Healthcare.

\section{Semi-quantitative RT-PCR}

Cells under different culture conditions were treated with $5 \mu \mathrm{g} / \mathrm{ml}$ actinomycin $\mathrm{D}$, harvested at the indicated times, and total RNA was isolated using RNeasy mini kit (Qiagen) and treated with DNAseI (Promega) according to manufacturer's instructions. cDNA first strand was obtained with Transcriptor Reverse Transcriptase (Roche) using $250 \mathrm{ng}$ of total RNA and oligo-dT primer. PCR reactions were performed using the sequence-specific primers listed in Table 2 of the Additional Data. $\beta 2$-microglobulin was used as an internal control for normalizing transcripts levels measured by RT-PCR. To optimize RT-PCR, preliminary dose-response experiments were performed to determine the range of first strand cDNA concentrations at which PCR amplification was linear for each target molecule essentially as reported in Briata et al. [11]. For each species of RNA analyzed, the amount of RT-PCR product (measured as densitometric units) was plotted against the input of first strand cDNA.

\section{Abbreviations}

ARE, AU-rich element;

ARE-BP, ARE binding protein;

$\beta 2-\mathrm{MG}, \beta 2-\mathrm{microglobulin} ;$

KH, K-homology;

myrAKT1, myristylated form of AKT1;

PI3K, phosphatidylinositol 3-kinase;

PP2A, Protein phosphatase 2A;

t1/2, half-life.

\section{Authors' contributions}

TR, MT, and MP performed the experiments; GC contributed analysis tools; C-YC contributed reagents and discussed data; LA-H performed experiments; KSAK performed experiments, acquired and analyzed data, reviewed the manuscript; $\mathrm{PB}$ and RG conceived, designed and performed the experiments, analyzed the data, and wrote the manuscript. all authors read and approved the final manuscript. PB and RG equally contributed to this work.

\section{Additional material}

\section{Additional file 1}

Features of $c D N A$ s probes present in the AU-rich element based microarrays. list of the features of CDNA sequences present in the AU-rich element based microarrays.

Click here for file

[http://www.biomedcentral.com/content/supplementary/1471-

2199-8-28-S1.pdf]

\section{Additional file 2}

ARE-like motifs are prevalently represented among KSRP target transcripts when compared to non-KSRP targets. the table provides consensus motifs for KSRP target transcripts as derived from bioinformatics analysis of AU-rich element based microarrays screenings.

Click here for file

[http://www.biomedcentral.com/content/supplementary/1471-

2199-8-28-S2.pdf]

\section{Additional file 3}

Distribution of average C $y 5 / C \gamma 3$ fluorescence ratios from two independent microarray hybridizations. $1.5 \log _{2}$ has been chosen as the threshold applied for defining 80 target genes (the inset shows a magnification of the enriched region). Data represent average Cy5/Cy3 fluorescence ratios from two independent hybridizations of the AU-rich element based microarrays.

Click here for file

[http://www.biomedcentral.com/content/supplementary/14712199-8-28-S3.tiff]

\section{Additional file 4}

Sequence of the ARE-containing 3 'UTR regions of KSRP target transcripts cloned into $P C Y$ vector. Canonical ARE pentamers are highlighted in yellow while U-rich stretches are underlied. the files provides the sequence of the 3' UTRs of KSRP target transcripts.

Click here for file

[http://www.biomedcentral.com/content/supplementary/1471-

2199-8-28-S4.pdf]

\section{Additional file 5}

AUF1 interacts very weakly with PTMA and hnRNPA/B mRNAs in $\alpha \mathrm{T} 3-$ 1 cells. The figure shows representative immunoprecipitation experiments of AUF1-containing ribonucleoprotein complexes containing either PTMA or hnRNPA/B mRNAs.

Click here for file

[http://www.biomedcentral.com/content/supplementary/1471-

2199-8-28-S5.tiff]

\section{Additional file 6}

KSRP knock-down prolongs the t(1/2) of KSRP target transcripts. Halflives are expressed in minutes and were calculated on the basis of data presented in Figure 3C. The table shows the half-lives (in minutes) of KSRP target transcripts calculated on the basis of diagrams presented in Figure 3C. Data for both mock-transfected and shKSRP-transfected cells are presented.

Click here for file

[http://www.biomedcentral.com/content/supplementary/1471-

2199-8-28-S6.pdf] 


\section{Additional file 7 \\ PI3K-AKT signaling prolongs the $t(1 / 2)$ of a set of KSRP-interacting $m R N A s$. Half-lives are expressed in minutes and were calculated on the basis of data presented in Figure 4C. The table shows the half-lives (in minutes) of KSRP target transcripts calculated on the basis of diagrams presented in Figure 4C. Data for both mock-transfected and myrAKT1- transfected cells are presented. \\ Click here for file \\ [http://www.biomedcentral.com/content/supplementary/1471- 2199-8-28-S7.doc]}

\section{Additional file 8}

Both the stability and the steady-state levels of prothymosin $\alpha$ (PTMA) $m R N A$ are regulated by KSRP while are unaffected by AKT1 activation. The Figure shows that KSRP can regulate by itself both the stability and the steady-state levels of PTMA while these parameters are not affected by activation of AKT1 in the same cells. This suggests that not all KSRP target transcripts are controlled by PI3K-AKT signaling.

Click here for file

[http://www.biomedcentral.com/content/supplementary/14712199-8-28-S8.tiff]

\section{Additional file 9}

A working hypothesis for KSRP-mediated stabilization of PP2ACA mRNA in response to PI3K-AKT signaling activation. The cartoon presents a speculation on the potential interplays existing in the PI3K-AKT signaling pathway through the intervention of KSRP.

Click here for file

[http://www.biomedcentral.com/content/supplementary/14712199-8-28-S9.tiff]

\section{Additional file 10}

Primers used for RT-PCR reactions. The table shows a list of the transcript-specific primers used in RT-PCR reactions in order to analyze the expression of KSRP target transcripts.

Click here for file

[http://www.biomedcentral.com/content/supplementary/14712199-8-28-S10.pdf]

\section{Acknowledgements}

The authors thank Ms. Hana Abulleef for her bioinformatics assistance. We are indebted with Dr. G. Dreyfuss for antibodies. M.T. present address is: George Palade Laboratories, University of California San Diego, 9500 Gilman Drive, La Jolla, CA 92093-0648 USA. This work has been partly supported by grants from Associazione Italiana Ricerca sul Cancro, AIRC (to RG), Fondazione Telethon (GGP040 I2, to PB), and FISM (to GC). TR was supported by a fellowship from FIRC, MT was supported by an American Italian Cancer Foundation fellowship. PB is recipient of a Senior Scholar Consultancy from the American Italian Cancer Foundation

\section{References}

I. Wilusz CJ, Wilusz J: Bringing the role of mRNA decay in the control of gene expression into focus. Trends Genet 2004, 20:491-497.

2. Bakheet T, Williams BR, Khabar KS: ARED 3.0: the large and diverse AU-rich transcriptome. Nucleic Acids Res 2006, 34:DIII-II4.

3. Audic $\mathrm{Y}$, Hartley RS: Post-transcriptional regulation in cancer. Biol Cell 2004, 96:479-498.

4. Kontoyannis D, Pasparakis M, Pizarro TT, Cominelli F, Kollias G: Impaired on/off regulation of TNF biosynthesis in mice lack- ing TNF AU-rich elements: implications for joint and gutassociated immunopathologies. Immunity 1999, 10:387-398.

5. Loflin $P$, Chen $C Y$, Shyu $A B$ : Unraveling a cytoplasmic role for hnRNP $D$ in the in vivo mRNA destabilization directed by the AU-rich element. Genes Dev 1999, I3:1884-1897.

6. Lu JY, Sadri N, Schneider RJ: Endotoxic shock in AUFI knockout mice mediated by failure to degrade proinflammatory cytokine mRNAs. Genes Dev 2006, 20:3 I 74-3184.

7. Gherzi R, Lee KY, Briata P, Wegmuller D, Moroni C, Karin M, Chen C-Y: A KH domain RNA binding protein, KSRP, promotes ARE-directed mRNA turnover by recruiting the degradation machinery. Mol Cell 2004, 14:57|-583.

8. Lykke-Andersen J, Wagner E: Recruitment and activation of mRNA decay enzymes by two ARE-mediated decay activation domains in the proteins TTP and BRF-I. Genes Dev 2005, 19:35I-36I.

9. Chou CF, Mulky A, Maitra S, Lin WJ, Gherzi R, Kappes J, Chen C-Y: Tethering KSRP, a decay-promoting AU-rich element-binding protein, to mRNAs elicits mRNA decay. Mol Cell Biol 2006, 26:3695-3706.

10. Briata P, llengo C, Corte G, Moroni C, Rosenfeld MG, Chen C-Y, Gherzi R: The Wnt/ $\beta$-catenin>Pitx2 pathway controls the turnover of Pitx 2 and other unstable mRNAs. Mol Cell 2003 , I2:|20|-|2||.

II. Briata P, Forcales SV, Ponassi M, Corte G, Chen C-Y, Karin M, Puri PL, Gherzi R: p38-dependent phosphorylation of the mRNA decay-promoting factor KSRP controls the stability of select myogenic transcripts. Mol Cell 2005, 20:89I-903.

12. Gherzi R, Trabucchi M, Ponassi M, Ruggiero T, Corte G, Moroni C, Chen C-Y, Khabar KS, Andersen JS, Briata P: The RNA-binding protein KSRP promotes decay of $\beta$-catenin MRNA and is inactivated by PI3K-AKT signaling. PLoS Biol 2007, 5:82-95.

13. Linker K, Pautz A, Fechir M, Hubrich T, Greeve J, Kleinert H: Involvement of KSRP in the post-transcriptional regulation of human iNOS expression-complex interplay of KSRP with TTP and HuR. Nucleic Acids Res 2005, 33:48I 3-4827.

14. Keene JD, Lager PJ: Post-transcriptional operons and regulons co-ordinating gene expression. Chromosome Res 2005, I 3:327-337.

15. Khabar KS, Al-Haj L, Al-Zoghaibi F, Marie M, Dhalla M, Polyak SJ, Williams BR: Expressed gene clusters associated with cellular sensitivity and resistance towards anti-viral and antiproliferative actions of interferon. J Mol Biol 2004, 342:833-846.

16. Trifillis P, Day N, Kiledjian M: Finding the right RNA: identification of cellular mRNA substrates for RNA-binding proteins. RNA 1999, 5:1071-1082.

17. Lal A, Mazan-Mamczarz K, Kawai T, Yang X, Martindale JL, Gorospe $\mathrm{M}$ : Concurrent versus individual binding of HuR and AUFI to common labile target mRNAs. EMBO J 2004, 23:3092-I02.

18. Chen CY, Gherzi R, Ong SE, Chan EL, Raijmakers R, Pruijn G], Stoecklin G, Moroni C, Mann M, Karin M: AU binding proteins recruit the exosome to degrade ARE-containing mRNAs. Cell 200I, 107:45I-64.

19. Hamilton BJ, Burns CM, Nichols RC, Rigby WF: Modulation of AUUUA response element binding by heterogeneous nuclear ribonucleoprotein $A I$ in human $T$ lymphocytes. The roles of cytoplasmic location, transcription, and phosphorylation. J Biol Chem 1997, 272:28732-2874l.

20. Frevel MA, Bakheet T, Silva AM, Hissong JG, Khabar KS, Williams BR p38 Mitogen-activated protein kinase-dependent and independent signaling of mRNA stability of AU-rich elementcontaining transcripts. Mol Cell Biol 2003, 23:425-36.

21. Townley-Tilson WH, Pendergrass SA, Marzluff WF, Whitfield ML: Genome-wide analysis of mRNAs bound to the histone stem-loop binding protein. RNA 2006, I 2: I853-I867.

22. Lopez de Silanes I, Galban S, Martindale JL, Yang X, Mazan-Mamczarz $\mathrm{K}$, Indig FE, Falco G, Zhan M, Gorospe M: Identification and functional outcome of mRNAs associated with RNA-binding protein TIA-I. Mol Cell Biol 2005, 25:9520-953I.

23. Ule J, Ule A, Spencer J, Williams A, Hu JS, Cline M, Wang H, Clark T, Fraser C, Ruggiu M, Zeeberg BR, Kane D, Weinstein JN, Blume J, Darnell RB: Nova regulates brain-specific splicing to shape the synapse. Nat Genet 2005, 37:844-852.

24. Kim Guisbert K, Duncan K, Li H, Guthrie C: Functional specificity of shuttling hnRNPs revealed by genome-wide analysis of their RNA binding profiles. RNA 2005, I I:383-393. 
25. Penalva LO, Burdick MD, Lin SM, Sutterluety H, Keene JD: RNAbinding proteins to assess gene expression states of co-cultivated cells in response to tumor cells. Mol Cancer 2004, 3:24-35.

26. Patel NA, Kaneko S, Apostolatos HS, Bae SS, Watson JE, Davidowitz K, Chappell DS, Birnbaum MJ, Cheng JQ, Cooper DR: Molecular and genetic studies imply Akt-mediated signaling promotes protein kinase $\mathbf{C}$ betall alternative splicing via phosphorylation of serine/arginine-rich splicing factor SRp40. J Biol Chem 2005, 280: |4302-|4309.

27. Blaustein M, Pelisch F, Tanos T, Munoz MJ, Wengier D, Quadrana L, Sanford JR, Muschietti JP, Kornblihtt AR, Caceres JF, Coso OA, Srebrow A: Concerted regulation of nuclear and cytoplasmic activities of SR proteins by AKT. Nat Struct Mol Biol 2005, 1 2:1037-1044.

28. Rooke N, Markovtsov V, Cagavi E, Black DL: Roles for SR proteins and hnRNP Al in the regulation of c-src exon NI. Mol Cell Biol 2003, 23: $1874-1884$

29. Bastepe M, Juppner H: GNAS locus and pseudohypoparathyroidism. Horm Res 2005, 63:65-74.

30. Chen M, Haluzik M, Wolf NJ, Lorenzo J, Dietz KR, Reitman ML, Weinstein LS: Increased insulin sensitivity in paternal Gnas knockout mice is associated with increased lipid clearance. Endocrinology 2004, 145:4094-4I02.

31. Janssens V, Goris J: Protein phosphatase 2A: a highly regulated family of serine/threonine phosphatases implicated in cell growth and signalling. Biochem / 200I, 353:4I 7-439.

32. Bos CL, Diks SH, Hardwick JC, Walburg KV, Peppelenbosch MP, Richel $D$ J: Protein phosphatase $2 A$ is required for mesalazinedependent inhibition of $\mathrm{Wnt} /$ beta-catenin pathway activity. Carcinogenesis 2006, 27:2371-2382.

33. Bos CL, Kodach LL, van den Brink GR, Diks SH, van Santen MM, Richel DJ, Peppelenbosch MP, Hardwick JC: Effect of aspirin on the Wnt/beta-catenin pathway is mediated via protein phosphatase 2A. Oncogene 2006, 25:6447-6456.

34. Millward TA, Zolnierowicz S, Hemmings BA: Regulation of protein kinase cascades by protein phosphatase $2 \mathrm{~A}$. Trends Biochem Sc 1999, 24:|86-|9|.

35. Lin WH, Huang CJ, Liu MW, Chang HM, Chen YJ, Tai TY, Chuang LM Cloning, mapping, and characterization of the human sorbin and $\mathrm{SH} 3$ domain containing I (SORBSI) gene: a protein associated with c-Abl during insulin signaling in the hepatoma cell line Hep3B. Genomics 200I, 74:12-20.

36. Zhang M, Liu J, Cheng A, Deyoung SM, Chen X, Dold LH, Saltiel AR: CAP interacts with cytoskeletal proteins and regulates adhesion-mediated ERK activation and motility. EMBO J 2006 , 25:5284-5293.

37. Kioka N, Ueda K, Amachi T: Vinexin, CAP/ponsin, ArgBP2: a novel adaptor protein family regulating cytoskeletal organization and signal transduction. Cell Struct Funct 2002, 27: I-7.

38. Katsanakis KD, Pillay TS: Cross-talk between the two divergent insulin signaling pathways is revealed by the protein kinase $B$ (Akt)-mediated phosphorylation of adapter protein APS on serine 588. J Biol Chem 2005, 280:37827-37832.

39. Krimer DB, Cheng G, Skoultchi Al: Induction of $\mathbf{H 3 . 3}$ replacement histone mRNAs during the precommitment period of murine erythroleukemia cell differentiation. Nucleic Acids Res 1993, $21: 2873-2879$

40. Hake $S B$, Allis $C D$ : Histone $\mathbf{H} \mathbf{3}$ variants and their potential role in indexing mammalian genomes: the " $\mathrm{H} 3$ barcode hypothesis". Proc Natl Acad Sci USA 2006, 103:6428-6435.

4I. Knowles HJ, Phillips RM: Identification of differentially expressed genes in experimental models of the tumor microenvironment using differential display. Anticancer Res 200I, $21: 2305-23$ II.

42. Listerman I, Sapra AK, Neugebauer KM: Cotranscriptional coupling of splicing factor recruitment and precursor messenger RNA splicing in mammalian cells. Nat Struct Mol Biol 2006 , 13:815-822.

43. Zhang QS, Manche L, Xu RM, Krainer AR: hnRNP AI associates with telomere ends and stimulates telomerase activity. RNA 2006, I 2:1 I|16-II28.

44. Thijs G, Lescot M, Marchal K, Rombauts S, De Moor B, Rouzé P, Moreau $Y$ : A higher order background model improves the detection of regulatory elements by Gibbs Sampling. Bioinformatics 2001, 17:1113-1122.
45. Raghavana A, Dhalla M, Bakheet T, Ogilvie R, Vlasova IA, Khabar KSA, Williams BRG, Bohjanen PR: Patterns of coordinate down-regulation of ARE-containing transcripts following immune cell activation. Genomics 2004, 84:1002-1013.

46. Chen C-Y, Gherzi R, Andersen JS, Gaietta G, Jürchott K, Royer HD, Mann M, Karin M: Nucleolin and YB-I are required for JNKmediated interleukin-2 mRNA stabilization during T-cell activation. Genes Dev 2000, 14:1236-1248.
Publish with BioMed Central and every scientist can read your work free of charge

"BioMed Central will be the most significant development for disseminating the results of biomedical research in our lifetime. "

Sir Paul Nurse, Cancer Research UK

Your research papers will be:

- available free of charge to the entire biomedical community

- peer reviewed and published immediately upon acceptance

- cited in PubMed and archived on PubMed Central

- yours - you keep the copyright
BioMedcentral 